\title{
Leucine-Rich Repeat-Containing Protein
} 19

National Cancer Institute

\section{Source}

National Cancer Institute. Leucine-Rich Repeat-Containing Protein 19. NCI Thesaurus.

Code C104619.

Leucine-rich repeat-containing protein 19 (370 aa, 42 kDa) is encoded by the human

LRRC19 gene. This protein may play a role in inducing innate immune responses in kidney and other tissues. 